\title{
Community perceptions of coral reef conservation in a rural fishing village in North Bali, Indonesia.
}

\section{Zach Boakes ( $\nabla$ zboakes@bournemouth.ac.uk)}

Bournemouth University

Luh Putu Mahyuni

Universtias Pendidikan Nasional

\section{Richard Stafford}

Bournemouth University

Marin Cvitanovic

Bournemouth University

\section{Article}

Keywords: Coral reef conservation, community perceptions of conservation, positive environmental behaviours, qualitative research, ecotourism in Bali and Indonesia

Posted Date: February 22nd, 2022

DOI: https://doi.org/10.21203/rs.3.rs-1374792/v1

License: (1) (1) This work is licensed under a Creative Commons Attribution 4.0 International License. Read Full License 


\section{Abstract}

Aside from their associated direct ecological advantages, coral reef conservation programs may also generate benefits to local communities. These communities may choose to support marine conservation programs based on multiple factors, and an increased involvement of local people often leads to positive changes in environmental behaviours. This study collected qualitative data using semi-structured interviews and multi-stakeholder focus groups on a rural fisher community in Tianyar Village, North Bali, Indonesia, where the 'North Bali Reef Conservation' (locally known as 'Yowana Bhakti Segara') coral reef conservation program was based. Results showed that generally, the community of Tianyar village was in support of the existing coral reef conservation programs, mostly due to the perceived economic prospects associated with being involved in the conservation work. Overall, the community agreed that the coral reef conservation program has led to societal and environmental benefits, which has generated positive environmental behaviours and a change in mindsets since it was established in 2017 (4 years before this study was undertaken). Based on the answers of interviewees, this study makes recommendations on how coral reef conservation in Bali (and other similar less developed nations) can increase community support, socio-economic benefits and positive environmental behaviours. These include (1) continuing environmental education for within the community, (2) strengthening regulations and improving enforcement, (3) increasing financial and logistical support for waste management and ecotourism, (4) continuing building and deploying artificial reefs, ensuring that 'best practice' recommendations are followed, and (5) utilising the influence of local leaders to create positive environmental behaviours.

\section{Introduction}

Coral reefs are critically important to tropical coastlines, providing ecosystem services such as food provision, shoreline protection, biogeochemical cycling and tourism ${ }^{1,2}$, which are estimated at a value of over US $\$ 1$ Trillion globally ${ }^{3}$. However, the health of global coral reefs is declining at rates unprecedented in human history 4,5 , resulting in losses in associated biodiversity, abundance and habitat structure in recent decades ${ }^{6,7}$. Climate change induced coral bleaching is identified as the main reason for coral reef degradation worldwide ${ }^{4,8}$, with other localised issues such as destructive/over-exploitative fishing techniques ${ }^{9}$, nutrient enrichment ${ }^{10}$ and pollution ${ }^{11}$ posing additional threats to these ecosystems. ${ }^{12}$ showed that that climate-related losses of reef ecosystem services will total approximately US $\$ 500$ billion by 2100 , with the greatest of these impacts experienced by people who rely upon reef services for day-to-day subsistence.

As well as global greenhouse gas emission reduction at an international level, multiple small-scale tools may be considered by local communities to conserve, restore and increase the resilience of their local coral reefs. These methods may include coral transplantation ${ }^{13,14}$, building coral nurseries ${ }^{15,16}$ which may include coral species that are resistant to bleaching ${ }^{17,18}$, community development and education ${ }^{19}$, marine protected area establishment ${ }^{20,21}$ and constructing artificial reefs (ARs) ${ }^{23,24}$. Whilst these 
methods may be unable to conserve large-scale ecosystem function and processes ${ }^{25}$, they have been shown to provide some degree of protection at a localised level and in some cases, restore localised ecosystem services in areas which have lost reefs. Each method varies in terms of its overall effectiveness, implementation feasibility and how well researched it is.

\section{Community coral reef conservation}

As discussed by ${ }^{5}$, for community-level coral reef conservation to occur on a scale large enough to generate meaningful and substantial change, it is necessary to create 'ocean empathy' (herein OE), which is described as "taking the perspective of, and feeling an emotional bond with, ocean-dependent communities, marine organisms and marine ecosystems". Research has highlighted that low OE has led to ocean health not being prioritised, for example ${ }^{26}$ found that 3,500 world leaders consider the SDG 14 (Life Below Water) target to be the least important of the UN's Sustainable Development Goals. Increased OE within communities living close to coral reefs would lead to the local population safeguarding their marine environment ${ }^{5}$, which is important given that local communities play a vital role in the sustainability of all conservation programmes ${ }^{27}$, and often drive a conservation project's overall success 28,29 .

Research has highlighted that education focused on environmental protection has potential to increase immediate and long-term community support for conservation ${ }^{30,31}$. However, multiple studies on different worldwide conservation projects have highlighted that an increase in knowledge alone, is insufficient in driving substantial changes the communities behaviour and attitude, with regards to boosting conservation support $27,28,32$. For a programme to maintain long-term, sustainable community support, the following factors are also important: (1) Perceived personal benefit, most often a financial gain arising from the conservation work (e.g. a fisher increasing yield due to higher fish biomass) ${ }^{33}$, (2) inclusion of local people in conservation decision-making processes ${ }^{34}$, (e.g. compliance of marine protected area (MPA) regulations have been shown to be higher when local fishers are involved in establishment and enforcement ${ }^{35}$ ), (3) Influence from local leaders, which have been shown to 'bridge the gap' between local people and marine conservation objectives ${ }^{28}$, and (4) increased community $\mathrm{OE}$, which is often driven by visual media, for example somebody supporting marine conservation objectives after seeing photos on social media of marine life harmed by plastic pollution ${ }^{5}$.

\section{The coral reefs of Bali, Indonesia}

Indonesia makes up $12.5 \%$ of the world's total coral reef area ${ }^{36}$. It sits within the Coral Triangle, an area recognised as the global centre of marine biodiversity ${ }^{37}$ which is of global conservation importance ${ }^{38}$. Bali is a province of Indonesia (Figure 1), and has the second highest documented reef fish species richness in the Asia-pacific ${ }^{39}$, with at least 805 documented fish species ${ }^{40}$. Given the global decline in coral reef health, it is unsurprising that $86 \%$ of Indonesia's coral reefs face medium or high levels of threat ${ }^{41}$. Studies on Bali's reefs in 2011, collected from the 27 reefs across the island, showed that its corals 
were generally in good condition ${ }^{42}$. More recent data from 2017 has highlighted similar results, suggesting that $50 \%$ of its corals are in good health, whilst $20 \%$ are declining and $30 \%$ are poor (Marine and Fisheries Office 2017 data, as cited by ${ }^{43}$. The primary reasons for declines in Bali's coral reef health are associated with coral bleaching ${ }^{44-46}$ and destructive fishing practices ${ }^{47,48}$, although multiple other threats also persist.

'Ecological restoration' is defined as "the process of assisting the recovery of an ecosystem that has been degraded, damaged, or destroyed" ${ }^{49}$. In comparison, 'ecological conservation' is a slightly broader term, which incorporates preservation and protection, as well as restoration ${ }^{50}$. Following a decline in coral health in recent decades, the active restoration and conservation of Bali's reefs has been initiated by community groups, international NGOs and the government (both on a local and central scale). Of the conservation/ restoration tools Bali has used, some of the most notable include establishing three marine protected areas ${ }^{20}$, deploying artificial reefs as a habitat enhancement tools on many degraded reefs around the island ${ }^{43}$ and developing ecotourism destinations which promote coral reef conservation ${ }^{28}$.

International research generally agrees that involvement of the local community is imperative to the success of a coral reef conservation program, in terms of removing initial reef threats and also sustainable program management ${ }^{51-53}$. Tightly knit fisher communities are a common feature of coastal villages in Bali because fisher groups frequently gather for the planning and implementation of regular community events and religious ceremonies ${ }^{54}$. The involvement of these community groups is important for the success of a sustainable marine management programme in Bali ${ }^{5}$.

Previous studies from within Bali have documented that sustainability-related programs obtain greater support from the wider community when the initial initiative from certain community groups is brought into a larger community meeting - called a desa adat meeting (see Table 3 glossary in results section), to

produce a general agreement within the larger community 56,57 . Once these programs gain approval from desa adat, a budget is often allocated to support the implementation of the program. Local influential leaders and NGOs play substantial roles in bridging communication between international, local experts and leaders of desa adat to achieve general agreement about the importance of sustainability-related programs implementation ${ }^{56}$.

\section{Research aims}

This introduction has highlighted the threats, and consequential degradation of coral reefs, globally and in Bali. It has discussed some of the main local-level restoration tools which may be used by communities that wish to protect their coral reefs. Although literature has shown the importance of community support for coral reef conservation, there is a relatively limited amount of published international research which addresses community perceptions of these types of projects, as well as how they can generate positive environmental behaviours locally. Research that does focus on this topic appears to be have been predominantly conducted in the West, and is especially under-researched and generally non-English speaking countries like Indonesia. 
The aim of this qualitative research is to examine how the local community in Tianyar Village perceive the benefits of coral reef conservation, and to also assess the extent to which coral reef conservation has generated positive environmental behaviours within the village. This research is important because it provides a voice for communities that are generally under-represented within international research, and based on their opinions, makes a unique set of recommendations for better conserving coral reefs.

\section{Methods}

\section{Location}

Qualitative data was collected in Tianyar Village, North East Bali. Tianyar Village is in Bali's Karangasem regency, where primary job occupations are dominated by fishing and selling fish ${ }^{58}$. Its $3 \mathrm{~km}$ coastline consists of areas with healthy coral reefs, as well as empty areas where reefs were previously destroyed by unsustainable fishing techniques and boat anchoring. Tianyar village receives relatively few tourists, especially in comparison to other mass tourism areas in the south of the island.

Data was collected in a community where the coral reef conservation Non-Government Organisation 'North Bali Reef Conservation' (locally known as 'Yowana Bhakti Segara') was based. This NGO, which was established in 2017, is well known for its community coral reef conservation efforts, notably deploying approximately 8000 artificial reef (AR) structures (of the size $1 \mathrm{~m} \times 0.5 \mathrm{~m}$ ) in areas of previously destroyed reef. These ARs sit inside a no-take-zone marine protected area (MPA), which was established and enforced by the local community. This work has successfully restored areas of reef in North Bali, which has allowed marine biodiversity to return to a biological community that is similar to a nearby natural healthy reef (Boakes et al., in review).

\section{Interview process}

Data collection consisted of semi-structured interviews and two multi-stakeholder focus groups with the local community in Tianyar Village between July-August 2021. Following the methods of ${ }^{59}$, in-depth, semi-structured interviews were conducted on 11 individuals who were key informants of groups over a cross section of the community, including: community leaders (from the local government, educational institutions, businesses and religious groups), fishers, fishmongers, tourism workers and school students. Interviewees were selected based on their willingness to be interviewed, although specific individuals/ groups were approached, based on factors such as age (e.g. students), gender and/or nature of employment (e.g. fishers), following ${ }^{60}$.

Data was also collected on two multi-stakeholder groups (following similar methods to ${ }^{61}$ ), each with 10 participants. Before all interviews and focus group discussions, respondents were asked to read a participant information document, which included information about Bournemouth University's ethical review process. Respondents were then required to indicate their consent regarding participation in the project. Following ${ }^{62}$, to reduce bias in the interviews, it was explained that the interviewees names and responses would remain anonymous within the research paper and publication. Each interviewee / focus 
group was given a code (e.g. interviewee 1 = I1 / focus group 1 = FG1), which was used instead of their name to ensure anonymity.

The interviews and focus groups were conducted in a mixture of locations, depending on the preference and availability of the interviewee. For instance, some interviewees (e.g. village leaders) requested that the interviews were conducted at their offices, whereas others (e.g. fishers or tourism workers) expressed no preference. In the instances where participants expressed no preference, interviews were conducted in community gathering/meeting areas. The interviews were conducted in a mixture of Indonesian and Balinese language. Interviews ranged from 30 minutes to 2 hours, and were recorded on a SONY ICD UX533F recorder.

The interviews and focus groups started with general questions or conversation topics such as "Tell me about your typical day", and then changed onto topics related to food, work or the marine environment (following ${ }^{63}$ ). The conversation then moved on to changes over the last five years, especially in terms of fishing and the marine environment. The final questions then specifically focused on marine conservation/ eco-tourism (similar to the methods of ${ }^{28}$ ), focusing on topics such as the role of education in coral reef conservation, community level support for coral reef conservation, and questions relating to tourism development.

\section{Sample size}

63 argues that "there are no rules for sample size in qualitative inquiry". The justification of sample size is particularly ambiguous, and often depends on the research topic, quality of data, cultural factors and the responses given by interviewees ${ }^{63,65,66}$. Some review papers have attempted provide guidance on sample sizes for qualitative research, such as ${ }^{67}$, who highlighted that from 560 studies, the mean sample size was 31 , or ${ }^{65}$, which suggested that single case studies should contain 15 to 30 interviews. However, qualitative researchers generally agree that, rather than pre-determining a sample size, it is better to finish data collection at the point of 'saturation' 67 ; when additional interviews no longer offer new insights and information about the given topic 68,69 . This study adopted a similar approach. Towards the end of the data collection process, it was decided that additional interviews were providing very little new information, with most interviews repeating opinions of previous interviewees. After collecting data on 31 participants, over a broad cross-section of the community (11 one-one interviews, and two focus groups each with 10 people), it was decided that the point of 'saturation' had been reached, and it was no longer necessary to continue the interviews.

\section{Qualitative analysis}

Interviews were translated into English and then transcribed (by authors fluent in both languages). This was done manually, given the lack of speech recognition software in Indonesian and Balinese languages. Then, following the methods of ${ }^{70}$, and the recommendations of ${ }^{71}$, authors listed key emerging ideas from the interviews, and key words (frequently used by interviewees as indicators of important themes) were $^{72}$. Following the thematic coding analysis guidelines of ${ }^{73}$, codes within the transcript were 
manually identified, and then categorised into the relevant themes. At this stage, particular attention was drawn to reoccurring themes that may have connecting and/or opposing views ${ }^{68}$. Next, the differences in answers between the interviews and focus groups were compared. It was decided that due to the similarity of answers between the two, findings would be presented jointly in the results section.

\section{Results And Discussion}

Table 1

Summary table of respondents' sociodemographic characteristics

\begin{tabular}{|llll|}
\hline Gender & \multicolumn{3}{l|}{ Occupation } \\
\hline Female & $27 \%$ & Government and policy & $18 \%$ \\
\hline Male & $73 \%$ & Education & $9 \%$ \\
\hline Prefer not to say & $0 \%$ & Tourism & $18 \%$ \\
\hline Age Group & & Fishing / selling fish & $36 \%$ \\
\hline $16-24$ & $9 \%$ & Non-government organisation & $9 \%$ \\
\hline $25-34$ & $18 \%$ & Student & $9 \%$ \\
\hline $35-44$ & $36 \%$ & Highest Level of Education & \\
\hline $45-54$ & $27 \%$ & Elementary school & $36 \%$ \\
\hline $55-64$ & $9 \%$ & Middle school & $27 \%$ \\
\hline 65 or over & $0 \%$ & High school & $18 \%$ \\
\hline Current Residency & & Undergraduate degree & $9 \%$ \\
\hline Tianyar Village, Bali & $100 \%$ & Postgraduate degree & $9 \%$ \\
\hline
\end{tabular}


Table 2

Summary of thematic analysis from the interviews with respondents.

\section{Theme Example of responses/ quotes}

Ecotourism development

Conservation efforts

Informal education

Current state of the marine environment

Environmental knowledge

Conservation support

Influence of foreigners
"There is a lot of potential in utilising the marine environment in terms of attracting ecotourism in the future".

"Coral conservation will restore the marine ecosystem and this could attract tourists to come, so we could get additional income from this"

"Conservation efforts have increased greatly in the village"

"We are spreading information about the importance of protecting the environment through community meetings and personal approaches"

"The corals are in an amazing state and the beach is much cleaner, thanks to the care of the local people and their programs"

"There hasn't been enough spreading of knowledge and as a result, most people's understandings of coral reef conservation is limited"

"We fully support the coral conservation program. We believe that the local economy will improve if marine tourism is developed, so that is why we support $i t^{\prime \prime}$.

"More international volunteers are coming here. They are helping to improve local people's English language skills, and making them more aware of the environment"

The importance of law enforcement

"Local policymakers have not done much to protect the environment"

"Patrolling by police and pecalang is needed to more strictly enforce rules"

Changes in the marine environment

"Before the conservation program started, there was only bare sand. Now, after we have deployed 7000 artificial reef structures, large numbers of fish and corals have come back"

Understanding of the importance of coral reefs

"Local people currently do not understand the ecological importance of coral reefs"

"The conservation program is very important for our future generations. This program could increase the potential of marine tourism development in this area"

Waste management

"There is still limited help from the government, and no trucks taking the plastic away"

Infrastructure investment

"We are lacking investment to support development for tourism, waste management and conservation.

Information through social media
"I get information about the threat to marine life through Instagram, for example turtles with straws in their noses, or birds tangled up in plastic" 


\section{Theme Example of responses/ quotes}

The level of formal education
"There is a link between the level of formal education and the level of environmental awareness"

"I don't think people who have a higher level of formal education necessarily have higher environmental awareness

Changes in locals' behaviour

Funding for conservation program

Adat rules for environmental protection

Perceived economic benefits

Experience in tourism

Local agents of change

Government role

Challenges in conservation efforts

Causes of coral destruction

Community agreement for environmental protection

Group rules
"Before I used to throw away my waste on the beach, or in the streams, but I now practice better self-waste management"

"The program gets funding from volunteer fees, which have been increasing significantly since early 2019, as it becomes more well-known among schools and universities abroad"

"There is no awig-awig (adat rules) for environmental protection"

"We are planning to create awig-awig (adat rules) to protect the marine environment"

"Perceived economic benefit is the dominant factor driving people's support for conservation efforts, not merely because they want to protect the environment".

"Foreigners have been visiting Tianyar since 2008 and this has been useful for fishermen and local children to practice their English"

"Local leaders play an important role in influencing local people to care for the environment, for example through beach cleaning, or turtle hatchling protection"

"Sometimes the conservation program gets funding from the central government of Indonesia through the Ministry of Marine Affairs and Fisheries"

"Some people argue when they are prohibited from fishing in the conservation area. It's also hard for us to remind our neighbours not to litter".

"Some corals previously got broken by my ancestors that used to take corals for building materials. Other factors include damaging fishing practices, such as using chemicals to catch ornamental fishes"

"We have made a community agreement related to environmental protection, such as coral protection, waste management and prohibition of using chemicals to catch fish"

"All members are required to protect the conservation area and they are not allowed to fish there". 
Table 3

Glossary of key words used by participants within interviews.

\section{Key Meaning \\ words}

Desa Customary village (semi-autonomous village governance system that is responsible for

Adat organising religious ceremonies and socio-cultural activities). Desa adat has the authority to produce its own rules based on a members agreement.

Desa Administrative village (village governance system that is responsible for managing

Dinas government-related administrative matters)

Banjar A small unit of a community group that share responsibilities to perform religious ceremonies and socio-cultural activities. Desa adat consists of several Banjars

Awig- $\quad$ Adat law

awig

Pecalang Desa adat security force

Yayasan Non-profit foundation

\section{Changes to the marine environment}

Recent data from 2017 has shown that that $50 \%$ of Bali's corals are in good health, whilst $20 \%$ are declining and $30 \%$ are poor ${ }^{43}$. The primary reasons for declines in Bali's coral reef health are associated with climate change-induced coral bleaching ${ }^{44-46}$ and destructive extractive practices such as overfishing and coral mining 47,48 . Whilst some threats to Bali's reefs, such as bleaching, appear to be widespread ${ }^{43-46}$, others, such as destructive extractive practices, have been shown to vary regionally across the island ${ }^{48}$. The interviews showed that past anthropogenic activities, notably coral mining, were responsible for coral degradation of the coral reef in Tianyar. In response to this destruction, interviewees describe the coral reef conservation work that has taken place. 11 explains that "Myself, alongside other fishers, started this conservation effort by establishing a foundation, called 'Yowana Bhakti Segara' in 2017. Before the conservation program started, there was only bare sand, but now after we have deployed around 7000 artificial reef structures, a large number of fish populations have come back again. The corals now grow by themselves, so natural recruitment is happening. Without our intervention to transplant the corals. I think this is a great achievement that we need to record". Many participants commented that this work has had direct benefits on the marine environment, commenting that after four years of conservation, the coral reef is now in good condition.

\section{Waste management}

Plastic pollution is another substantial threat to the marine environment in Bali, which declared a state of 'Garbage Emergency' in $2017^{74}$. Increased demand for single use plastics ${ }^{75}$, alongside a lack of expenditure in its waste management ${ }^{35}$ has led to Indonesia becoming the world's second largest plastic polluter ${ }^{76}$. Much of Bali's plastic is disposed of by being dumped in rivers or the sea, posing serious 
direct marine pollution threats ${ }^{77}$. A recent study on plastic pollution in South Bali indicated that microplastics are abundant in the marine environment ${ }^{78}$, whilst another showed that plastic abundance around the island may be as high as 449,000 pieces per $\mathrm{km}^{279}$. This level of plastic pollution is of concern due to plastics persistence in marine environment and its impact on wildlife and potentially humans ${ }^{80}$.

The responses from interviewees in this research also highlighted that waste management within the village is an issue. 15 explained that "There is still limited help from the government, and no trucks taking the plastic away. There is a plastic recycling centre here run by volunteers at NBRC [the conservation NGO], however it cannot recycle plastic bags and is only running on a small scale, so it cannot keep up with the plastic pollution problem in Tianyar". It appears, that despite the small-scale recycling programs run by the local conservation NGO, it appears "most waste goes into holes that are dug into the ground, or is burnt".

\section{Eco-tourism development}

Bali's economy is driven by tourism (pre-COVID-19 data), with 3.5 million international tourists and 7.3 million domestic tourists in $2018^{81}$. Tourism can lead to a substantial socio-economic benefits, especially in less developed countries, notably through providing new jobs to local people ${ }^{82}$. However, tourism has been criticised for destroying Bali's rich culture and high biodiversity ${ }^{83,84}$. For example, certain villages within South Bali were previously recognised for religious ceremonies and traditional music, however since the influx of tourism, they have been criticised for losing their cultural heritage, and are now associated with westernised drinking and drug problems ${ }^{83}$. Mass tourism within Bali has also been associated with water pollution due to insufficient waste management, as well as water scarcity and loss of ecologically diverse and agriculturally productive land ${ }^{85}$.

Eco-tourism is defined as responsible travel to natural areas that conserves the environment and sustains the well-being of local people ${ }^{86}$. There are multiple examples from within Bali highlighting that ecotourism can successfully generate socio-economic benefits, whilst protecting (and often actively conserving) the local environment. For example, the 'Turtle Conservation and Education Centre' in Serangan Island, South Bali, is a popular tourism attraction which uses money from tourism for the employment of local people to stop turtle poaching ${ }^{83}$. Another example is the Pemutaran Reef Restoration project in North West Bali, which, with the support of ecotourism, has allowed the development of marine conservation projects, including a turtle hatchling conservation (and adult rehabilitation) organisation ${ }^{44}$ and the Biorock ${ }^{\mathrm{TM}}$ artificial reef project ${ }^{87}$.

Generally, participants within this study showed great support for the development of eco-tourism in Tianyar, due to its potential to provide new, relatively well-paid jobs and improve livelihoods. This was highlighted by 11, who said "Tianyar has high potential to be developed as marine tourism destination, because we have very beautiful natural coral reefs and many variations of fish species", and I5, who mentioned "I am hoping to become a dive guide or instructor so that I can teach new guests to dive". 
Despite the general support for eco-tourism, the interviews highlighted lack of investment as the main factor stopping its development. ${ }^{88}$ discussed that regions in North Bali (such as Tianyar) receive relatively few tourists compared to Bali's mass tourism hub in the south of the island, and are consequently not a likely priority for investment.

Additionally, some participants, notably fishers, expressed concerns with the development of tourism in the area. For example FG1, said "We hope we can still do our job as fishers [after the development of marine tourism]. If we are marginalised, I think we will fight. It is very important to make conservation, tourism, and fishing zones". Additionally, 14 mentioned how the development of eco-tourism could lead to "potential issues with stakeholders, for example boat owners complaining about divers or snorkellers in the areas where they went to fish".

\section{Changes in fishing yield}

The topic of coral reef conservation (in this case ARs and MPAs) in terms of increasing fisheries yield, is highly complex and it is beyond the scope of this study to assess all factors which may affect this. However, research has shown that localised fisheries yield can increase as a result of ARs, through increased production of commercial species ${ }^{89,90}$, as well as MPA establishment, as a result of the 'spillover effect', as described and demonstrated by ${ }^{91,92}$. Some interviewees discussed this, such as 11 , who said "[because of the MPA and conservation work] fish have come back to the area, particularly fish that are commonly consumed by local people, such as snapper fish. There are [now] so many of them and this is benefitting local fishers".

Unsurprisingly, these coral reef conservation tools may not always result in direct benefits on localised fishing yields, for example if the ARs are deployed in a location that is unsuitable for increasing fish production ${ }^{93}$, or if the MPA is too small to generate benefits to mobile species ${ }^{94}$. Despite the described improvements in the general marine environment and coral reef health, fishers did not report experiencing an increase in fishing yield. For example, fishers in FG2 commented that "we haven't observed any significant changes in fishing yield over the past five years". This was agreed by most fishers interviewed. It is likely that one of the reasons fishers are not experiencing direct benefits from the conservation work is because the species they target are often caught far from the AR / MPA, and are not species which are generally found living on the artificial reef. It is also important to discuss that 'no change' in fishing yield may be positive, as literature has shown that MPA establishment can sometimes lead to initial reductions in yield, especially if the MPA prohibits fishing in a previously productive fishing area ${ }^{95}$.

Interestingly, there was a mixture of opinions regarding the potential of coral reef conservation to increase fishers' yield. For instance, 13 said that "I think there is no link between coral conservation and fish catch. Fishers don't catch fish in the conservation area because they want to catch pelagic fish, not reef fish". In contrast, I1 said "Small fish find shelter and algae to eat in the artificial reefs. Once they grow up, they move into the deep sea where the fishers can catch them. In my opinion, the artificial reef provides a habitat for fish to breed, and this could increase fishing yield". Literature has shown that effectively managed coral reef conservation programs which establish MPAs and/or deploy ARs, can lead to an 
increased fishing yield $89,91,92$, so it is recommended that more work is done to educate Tianyar's community about these advantages. This is discussed further later.

\section{Conservation support}

It appears that local people in Tianyar are supporting conservation, mostly due to potential financial benefits they may receive in future as a result of being involved. This was highlighted in multiple interviews, such as 17 who said "we want to support coral reef conservation to improve our job prospects in the future". Interestingly, the interviews showed that support for conservation, when driven by financial motivations, does not necessarily correspond with positive environmental behaviours. I1 said: "I don't think the local people genuinely care, or are aware about environmental protection. Even though they join conservation groups, I have observed that their actions are not representing environmental awareness at all. For instance, they keep throwing away waste while they are sitting on the beach". This describes support for conservation being driven by financial motivations, rather than genuine care for the environment. ${ }^{33}$ conducted a similar study on a fisher community in Bali and also highlighted that conservation efforts were largely driven by motivations to improve their livelihoods. ${ }^{96}$ highlighted that it can be problematic if support for marine conservation is driven purely by financial gain, because motivation to continue supporting conservation objectives may reduce if they experience a decrease in financial gain. A recent example of this occurring on a global scale, is the decline of support for conservation due to the COVID-19 pandemic. ${ }^{97}$ showed that conservation was one of the industries hit hardest by COVID-19. The authors discussed how threats to wildlife and conservation zones have been exacerbated during the pandemic as a result of increases in practices such as poaching, wildlife trafficking, and forest logging activities. ${ }^{98}$ specifically highlighted this occurrence in Indonesia, showing that the closure of marine eco-tourism spots due to lockdowns in Tegal, Java, harmed the local tourism economy and led to a decline of support for marine conservation work.

\section{Local awareness}

The interviews showed that there is limited awareness amongst the community with regards to the environment. For example, I3 said that "Local people lack knowledge and understanding about the importance of conserving the environment". FG1 explained that "Information about coral conservation and the environment has been spread traditionally through members meetings", and this is described by FG2 "an ineffective way of communicating environmental issues and coral reef conservation". As highlighted by the interviews, fishers have a relatively limited understanding of the economic benefits (as highlighted by the previously discussed literature) of coral reef conservation, specifically with regards to increased fishing yield.

\section{Formal education}

The interviews showed that there is very limited formal education in the Indonesian schooling curriculum with regards to environmental awareness; a view that is also supported by recent literature ${ }^{99} .11$ discussed the link between high-level formal education and environmental care, and said "I think there is a link between the level of formal education and the level of environmental awareness. Those who have 
studied [at university] in cities have seen good waste management systems, with waste bins and plastic sorting points. When they come back to the village they won't throw away their waste anymore, but will find a bin instead". This view is supported by international literature, which shows that higher levels of education generally fosters positive environmental attitudes ${ }^{100}$, with a study in Brazil highlighting that individuals with higher levels of education were 3.2 times more likely to have good environmental awareness than individuals with a lower level ${ }^{101}$.

This view is not shared by all participants, with 12 mentioning "I don't think those who have higher level of formal education have higher environmental awareness. Interacting with people and life experiences, I think, is more important than formal education". This, perhaps, reflects the relatively low level of education of participants and the general community within Tianyar Village. As highlighted by Table 1 , the highest level of education for $63 \%$ of participants was middle school. It was made clear from the interviews that many students in Tianyar leave education at a relatively young age, due to the cost of schooling and need to financially support their family, often becoming fishers and/or fish sellers.

\section{Informal education}

The interviews showed that an effective method of environmental education within the village has been through informal sessions with local children. 15 explained that "Before the educational program [Yayasan Widya Sari] started, most young people had no idea about the marine life on their beach. They now know how beautiful their local marine life is because they have been able to go snorkelling with international volunteers and see it. We have also had education at the Yayasan Widya Sari about fish identification, protecting corals and the marine environment". Literature has highlighted the importance of informal education as a powerful tool for generating environmentally friendly behaviours and ocean empathy 5,102 , especially when the sessions are delivered to young people in an outdoor environment ${ }^{103}$. ${ }^{99}$ highlighted the importance of environmental NGOs in Indonesia in exposing young people to envrionmental awareness and framing pro-environmental behaviours, especially given the lack of formal education on this topic. From the interviews, it appears that the youngest generation in Tianyar were the most aware about the environment, a general trend internationally, as highlighted by literarture (e.g. ${ }^{104}$ ). It is therefore recommended that this informal environmental education work continues.

It also appears that international volunteers have played an important role in terms of environmental education and knowledge within the village. As explained by 11, "Coral reef conservation activities here were first introduced by foreign volunteers. I previously had no idea about this sort of thing before that". 16 also mentioned that "Foreigners play an important and positive role in changing local peoples' environmental behaviours here". ${ }^{105}$ highlighted how conservation programs in less developed countries can benefit from foreign collaborations by utilising previously unavailable skills and knowledge. However, the author also discussed that foreign partners may expect the community to adopt their own philosophical and cultural beliefs and/or may demand a certain level of power or financial return. They therefore encourage local organisations to exercise caution before making international collaborations. 


\section{Social media as a tool for increasing education and knowledge}

Interestingly, social media, notably Instagram, may be an important source of environmental knowledge for participants. For example, I5 said "I get information about the dangers to marine life through Instagram, for example turtles with straws in their noses, or birds tangled up in plastic. Many local children follow conservation pages on Instagram. This is an effective method for spreading news about local marine life". Other participants also commented that they respond particularly well to videos compared to photos. Literature has highlighted the how social media can a powerful tool to promote education ${ }^{106}$, and has been shown to stimulate pro-environmental behaviours in some cases ${ }^{107}$. However research on this is generally inconclusive, with literature also highlighting that engagement in nature based social media may result in limited changes in pro-environmental behaviours ${ }^{5,108}$.

\section{Changes in local environmental behaviours}

As previously highlighted, the interviews have shown that knowledge on environmental issues / protection within Tianyar Village is limited. Despite this, the interviews do suggest that local people's behaviours have improved, in terms of environmental consciousness. For example, 19 said "Before we used to throw away waste on the beach, or dump it in the streams. We don't do this anymore, but instead now practice self-waste management". Not all participants agreed with this however. For example, 16 mentioned that "There are still quite a lot of older people who have little awareness or care about the environment. Some are still throwing away plastic in the environment". In this case, some interviewees said that throwing plastic away in the environment had stopped, whereas some interviews said it hadn't. It must be noted that the opposing opinions here may be due to the potential bias of some interviewees.

Literature has highlighted that sometime participants sometimes try to provide the interviewer with answers that they think is 'correct', rather than what is actually true ${ }^{109}$. In this case, it is possible that interviewees who said that the throwing away of waste no longer occurs, may be giving biased answers. Although this cannot be said for certain, the potential for bias must be acknowledged. It must be mentioned that there is potential for bias amongst all of the interviewees, for example policy makers being untruthful so that their work appears to be more impressive, or fishers speaking more positively about the conservation program because they get direct income from it. Measures were taken to reduce bias (as previously mentioned in the methods), but it the potential for bias here must still be acknowledged.

\section{Regulations and law enforcement}

Participants generally agree that local environmental regulations, as well as enforcement practices to support them, are insufficient. 14 also commented "We need more rules from the local government for environmental protection. Sometimes there are groups of people that don't agree with environmental protection, for example fishers". In contrast, 17 said "We haven't faced any challenges, so we don't feel it is necessary to develop laws around conservation. Instead we can do it through speaking with the 
community and persuading them". Although it appears that this opinion is not shared by the majority, views like this make explain the delay in / resistance for establishing official village regulations. Some respondents commented that plans are being developed to create regulations. For example 12 said "we are planning to create village rules to protect the environment, particularly the marine environment. But it may take quite a long time to do this".

Given responses from participants, it is expected that these regulations are well needed for effective environmental protection in Tianyar. 18 said that "authorities need to be involved with strictly enforcing environmental regulations. Otherwise local people will not follow them". This view is also highlighted by literature, for example ${ }^{48}$ discussed that poorly enforced regulations within the West Bali Marine Park MPA led to user non-compliance and suggests that enforcement of regulations by authorities are necessary for success of environmental regulations in Bali. Additionally, 14 commented that "There is a lack of communication of environmental rules and this needs to be made clearer. For example, sometimes fishers aren't certain if they're allowed to fish in an area or not - this is a common theme across Bali's marine protected areas". This is also supported by literature, for example, ${ }^{44}$ highlighted that unclear boundaries and zones within MPAs in Bali have led to fishers not complying with regulations.

\section{Local leaders}

The interviews highlighted the important role that local leaders play in promoting pro-environmental behaviours. For instance, 14 said "[local leader name] has an important role in influencing local people too, for example through beach cleaning, or turtle hatchling protection", and FG2 said "Local leaders encourage people that are throwing away litter, or demonstrating bad environmental behaviours, to change their habits. The leaders can influence people's behaviours". Local leaders, whom, in this case, demonstrate highly positive environmental behaviours and influence, are described by 11 to have "connected foreign volunteers and researchers with members of the fisher conservation group and the general community". Research has shown that the success of marine management programmes in Bali often relies on support from influential local leaders, which has been shown to 'bridge the gap' between Balinese people and marine conservation objectives ${ }^{28}$. For example, ${ }^{47}$ showed that local leaders associated with the 'LINI' NGO in Les Village, North Bali, have made great contributions towards encouraging local fishers to stop using destructive fishing methods.

\section{Recommendations}

\section{Continuing environmental education within the community}

The work of the 'Yayasan Widya Sar' (informal learning centre) is aiming to improve young people's awareness about environmental issues and marine conservation. As previously mentioned, global literature has highlighted the importance of informal education as a powerful tool for generating environmentally friendly behaviours and ocean empathy 5,102 , especially when the sessions are delivered to young people in an outdoor environment ${ }^{103}$. The work being done by this learning centre should be 
continued and supported due to its high potential to change mindsets and environmental behaviours of the youngest generation in Tianyar. Additionally, as mentioned by 14 " "Currently there is no formal education about this [the environment] in the schooling curriculum, but I think it very important and hope to develop plans like this soon". It is suggested that these plans are prioritised, for the same reasons as mentioned above.

As highlighted by the interviews, fishers have a relatively limited understanding of the economic benefits of coral reef conservation, specifically with regards to increased fishing yield. It is suggested that more work is done to increase their awareness on this topic, as it will likely generate more support for the conservation program. ${ }^{31}$ demonstrated that educating local communities about the socio-economic benefits of marine protected areas (MPAs) within Raja Ampat, Indonesia, led to a substantial increase in community compliance and active participation. The study suggests that investments in MPA education and outreach is an effective tool to engage communities in conservation objectives.

\section{Strengthening of regulations and improving enforcement}

Interviewees highlighted that environmental regulations within the village are weak / non-existent.

Research has shown that this is a reoccurring issue with regards to environmental protection in Bali ${ }^{44}$. It is suggested that the local government strengthens environmental regulations in the village, specifically with regards to waste management (and fines for disposing of waste on the beach etc), as well as creating clear zones for marine users. These regulations need to consider stakeholder opinions, and be well enforced by relevant enforcement bodies too, to ensure that regulations are followed by the community.

\section{Increasing financial and logistical support for waste management and ecotourism}

Many participants agreed that there is a lack of support for both the development of infrastructure for waste management and also ecotourism. In terms of waste management, it is suggested that the local government improves waste management and recycling infrastructure, as well as developing national legal frameworks and local level regulations which work with plastic producers and consumers ${ }^{74}$.

To develop ecotourism within the village, particularly for the very early stage of development, village leaders' ability to approach local government and access various government grants is crucial. Local universities might assist village leaders in creating blueprint of ecotourism development, thus increasing the chance of receiving various government grants. Aside from government grants, there are also various state-owned enterprises' and social responsibility funds that can be accessed to facilitate ecotourism infrastructure development within the village. As Tianyar continues to develop eco-tourism, it is recommended that stakeholder voices are carefully considered when establishing local regulations and policy. Literature, both worldwide ${ }^{110}$ and in Bali ${ }^{20}$, has shown that marine eco-tourism projects are far more likely to succeed when stakeholder opinions are listened to. 


\section{Continuing building and deploying artificial reefs, ensuring that 'best practice' recommendations are followed}

Literature has highlighted that ARs have been used in Bali as a habitat enhancement tool to successfully restore marine biodiversity and abundance ${ }^{111,112}$. In terms of achieving restoration objectives, it is important that programmes follow guidelines in light of 'best practice', as highlighted by Boakes et al., (in review). Additionally, the interviews showed that the artificial reef program is leading to other positive impacts (as well as the direct ecological benefits), as it appears to be increasing the communities awareness about/ support for environmental care, for example "the work done by the conservation program is increasing people's awareness about the environment". This is another compelling reason for the NGO to continue its work.

\section{Utilising the influence of local leaders to create positive environmental behaviours}

The interviews highlighted the important role that local leaders play in promoting pro-environmental behaviours. Literature has also shown that the success of marine management programmes in Bali often relies on support from influential local leaders, which has been shown to 'bridge the gap' between Balinese people and marine conservation objectives ${ }^{28}$. It appears there is potential for a great deal of positive change of environmental behaviours, if the influence of these community leaders is correctly utilised.

\section{Conclusion}

Generally there is a high level of community support for coral reef conservation in Tianyar Village. It appears that the driving force of this is due to the communities perceived economic prospects associated with conservation work, notably ecotourism development, which is also well supported by the local people. Fishers did not report experiencing increases in fishing yields as a result of the coral reef conservation program, but interviewees generally agreed that the program has led to an improvement in coral reef health and cleanliness of the village. The program was said to have generated positive environmental behaviours, in great part due to the support and influence of local leaders in the village. It is suggested that this influential work continues.

Awareness about marine conservation and the general environment amongst the community is limited, likely due to the lack of formal education on this topic. The 'Yayasan Widya Sari' learning centre has started to run informal education sessions with young people in the village, which appears to be creating ocean empathy and generating positive environmental behaviours amongst its students. It is suggested that environmental education should be prioritised in the local formal schooling curriculum, as well as being continued at the learning centre. 
The work of the conservation program (and its associated learning centre) alone, may not be enough to generate substantial environmental changes within the village. Interviewees highlighted that there is a lack of logistical and financial support for the development of ecotourism within the village. Increased support for this is suggested, so that local livelihoods can be improved and environmental care becomes a greater priority. The interviews also highlight a lack of infrastructure for waste management. It is important for the development of this infrastructure to be improved by the local government, as the village moves towards becoming an ecotourism destination. It is also suggested that the local government strengthens environmental regulations, as well as supporting these regulations with sufficient enforcement practices.

\section{Declarations}

\section{Conflict of interest}

The authors declare that they have no known competing financial interests or personal relationships that could have appeared to influence the work reported in this paper.

\section{Research ethics}

We further confirm that any aspect of the work covered has involved human participants was approved by the Bournemouth University Ethics Committee (reference number: 37431). Written consent to publish potentially identifying information, such as details or the case and photographs, was obtained from the patient(s) or their legal guardian(s).

\section{Data availability statement}

To remain GDPR compliant on the holding of social and economic data the aggregated data is available on request to the corresponding author.

\section{Permits}

A research permit was obtained from Indonesia's Ministry of Research (RISTEK).

Research permit number: 34/TU.B5.4/SIP/VII/2021

\section{Funding}

Zach Boakes, the first author of this paper, was supported by a studentship with Bournemouth University, UK. This research did not receive any other specific funding.

\section{References}

1. Moberg, F. \& Folke, C. Ecological goods and services of coral reef ecosystems. Ecol. Econ. 29, 215233 (1999). 
2. Principe, P. et al. Quantifying coral reef ecosystem services. US Environmental Protection Agency, Office of Research and Development, Research Triangle Park, NC. (2012).

3. Costanza, R. et al. Changes in the global value of ecosystem services. Glob. Environ. Chang. 26, 152-158 (2014).

4. IPCC. The Physical Science Basis. Contribution of Working Group I to the Sixth Assessment Report of the Intergovernmental Panel on Climate Change. (2021).

5. Blythe, J. et al. Fostering ocean empathy through future scenarios. People Nat. (2021).

6. Pandolfi, J. M., Connolly, S. R., Marshall, D. J. \& Cohen, A. L. Projecting coral reef futures under global warming and ocean acidification. Science (80-.). 333, 418-422 (2011).

7. Hughes, T. P. et al. Global warming transforms coral reef assemblages. Nature 556, 492-496 (2018).

8. Cornwall, C. E. et al. Global declines in coral reef calcium carbonate production under ocean acidification and warming. Proc. Natl. Acad. Sci. 118, (2021).

9. Bacalso, R. T. M. \& Wolff, M. Trophic flow structure of the Danajon ecosystem (Central Philippines) and impacts of illegal and destructive fishing practices. J. Mar. Syst. 139, 103-118 (2014).

10. Lapointe, B. E., Brewton, R. A., Herren, L. W., Porter, J. W. \& Hu, C. Nitrogen enrichment, altered stoichiometry, and coral reef decline at Looe Key, Florida Keys, USA: a 3-decade study. Mar. Biol. 166, 1-31 (2019).

11. Clukey, K. E. et al. Persistent organic pollutants in fat of three species of Pacific pelagic longline caught sea turtles: Accumulation in relation to ingested plastic marine debris. Sci. Total Environ. 610, 402-411 (2018).

12. Heron, S. F. et al. Impacts of climate change on World Heritage coral reefs: a first global scientific assessment. (2017).

13. Barton, J. A., Willis, B. L. \& Hutson, K. S. Coral propagation: a review of techniques for ornamental trade and reef restoration. Rev. Aquac. 9, 238-256 (2017).

14. Baria-Rodriguez, M. V., dela Cruz, D. W., Dizon, R. M., Yap, H. T. \& Villanueva, R. D. Performance and cost-effectiveness of sexually produced Acropora granulosa juveniles compared with asexually generated coral fragments in restoring degraded reef areas. Aquat. Conserv. Mar. Freshw. Ecosyst. 29, 891-900 (2019).

15. Endo, S., Prasetyo, R., Nishihira, M. \& Onaka, S. Experimental coral transplantation in the moat of Kuta beach, Bali Island, Indonesia. in PROCEEDINGS OF COASTAL ENGINEERING, JSCE vol. 55 1121-1125 (Japan Society of Civil Engineers, 2008).

16. Onaka, S., Prasetyo, R., Endo, S. \& Yoshii, I. Large-scale coral transplantation in artificial substrates at a shallow lagoon in Kuta Beach, Bali, Indonesia. Galaxea, J. Coral Reef Stud. 15, 336-342 (2013).

17. Morikawa, M. K. \& Palumbi, S. R. Using naturally occurring climate resilient corals to construct bleaching-resistant nurseries. Proc. Natl. Acad. Sci. 116, 10586-10591 (2019).

18. Camp, E. F. et al. Reef-building corals thrive within hot-acidified and deoxygenated waters. Sci. Rep. 7, 1-9 (2017). 
19. Sigit, D. V et al. Improvement of knowledge and attitude in conservation of mangrove and coral reefs through environmental education community network model. in vol. 131712201 (IOP Publishing, 2019).

20. Pedju, F. M. K. Stakeholders' perceptions of the impacts of tourism on the social and ecological resilience of marine protected areas in Bali, Indonesia. (2018).

21. Zhao, Q. et al. Where Marine Protected Areas would best represent $30 \%$ of ocean biodiversity. Biol. Conserv. 244, 108536 (2020).

22. Bohnsack, J. A. \& Sutherland, D. L. Artificial reef research: a review with recommendations for future priorities. Bull. Mar. Sci. 37, 11-39 (1985).

23. Baine, M. Artificial reefs: a review of their design, application, management and performance. Ocean Coast. Manag. 44, 241-259 (2001).

24. Keller, K. et al. Estimating the recreational harvest of fish from a nearshore designed artificial reef using a pragmatic approach. Fish. Res. 187, 158-167 (2017).

25. Pörtner, H.-O. et al. Ocean systems. in Climate change 2014: impacts, adaptation, and vulnerability. Part A: global and sectoral aspects. contribution of working group II to the fifth assessment report of the intergovernmental panel on climate change 411-484 (Cambridge University Press, 2014).

26. McDonnell, T. The UN Goal That Doesn't Get A Lot Of Respect. Retrieved 19, 2018 (2018).

27. Grúňová, M., Brandlová, K., Svitálek, J. \& Hejcmanová, P. Environmental education supports conservation action by increasing the immediate and long-term environmental knowledge of children in West Africa. Appl. Environ. Educ. Commun. 16, 3-16 (2017).

28. Trialfhianty, T. I. The role of the community in supporting coral reef restoration in Pemuteran, Bali, Indonesia. J. Coast. Conserv. 21, 873-882 (2017).

29. Wals, A. E. J. Learning our way out of unsustainability: The role of environmental education. in The Oxford handbook of environmental and conservation psychology (2012).

30. dos Santos, M. N., Monteiro, C. C. \& Lasserre, G. Observations and trends on the intra-annual variation of the fish assemblages on two artificial reefs in Algarve coastal waters (southern Portugal). Sci. Mar. 69, 415-426 (2005).

31. Leisher, C. et al. Measuring the benefits and costs of community education and outreach in marine protected areas. Mar. Policy 36, 1005-1011 (2012).

32. Brown, K., Eernstman, N., Huke, A. R. \& Reding, N. The drama of resilience: learning, doing, and sharing for sustainability. Ecol. Soc. 22, (2017).

33. Berkes, F. Linkages and multilevel systems for matching governance and ecology: lessons from roving bandits. Bull. Mar. Sci. 86, 235-250 (2010).

34. Lundquist, C. J. \& Granek, E. F. Strategies for successful marine conservation: integrating socioeconomic, political, and scientific factors. Conserv. Biol. 19, 1771-1778 (2005).

35. Glaser, M., Baitoningsih, W., Ferse, S. C. A., Neil, M. \& Deswandi, R. Whose sustainability? Top-down participation and emergent rules in marine protected area management in Indonesia. Mar. Policy 34, 
1215-1225 (2010).

36. Susiloningtyas, D., Handayani, T. \& Amalia, A. N. The impact of coral reefs destruction and climate change in Nusa Dua and Nusa Penida, Bali, Indonesia. in vol. 14512054 (IOP Publishing, 2018).

37. Allen, G. R. Conservation hotspots of biodiversity and endemism for Indo-Pacific coral reef fishes. Aquat. Conserv. Mar. Freshw. Ecosyst. (2008).

38. Briggs, J. C. The marine East Indies: diversity and speciation. J. Biogeogr. 32, 1517-1522 (2005).

39. Mustika, P. L. \& Ratha, I. Towards the Bali MPA Network. in Bali Marine Rapid Assessment Program 2011131 (BioOne, 2013).

40. Allen, G. R. \& Erdmann, M. V. Reef Fishes of Bali, Indonesia. in Bali Marine Rapid Assessment Program 201115 (BioOne, 2013).

41. Burke, L., Reytar, K., Spalding, M. \& Perry, A. Reefs at risk revisited in the Coral Triangle. (2012).

42. Lazuardi, M. E. et al. The Status of Coral Reefs in Bali. in Bali Marine Rapid Assessment Program 201169 (BioOne, 2013).

43. Wicaksana, I. B. A. 2020 Bali's Coral Conservation: from pandemic challenge to Government coral garden project. Bali Tour. J. 4, 35-39 (2020).

44. Suparno, N., Currier, K., Milner, C., Alling, A. \& Dustan, P. Ecological changes in the coral reef communities of Indonesia's Bali Barat National Park, 2011-2016. Atoll Res Bull 620, 1-35 (2019).

45. Tito, C. K., Ampou, E. E. \& Wibawa, T. A. Stressor-Response of Reef-Building Corals to Climate Change in the Menjangan Island, West Bali National Park, Indonesia. in vol. 24612011 (IOP Publishing, 2019).

46. Prasetia, D., Supriharyono, M., Anggoro, S. \& Sya'Rani, L. Coral Bleaching on Lembongan Island, Nusa Penida, Bali. in (Atlantis Press, 2017).

47. Frey, J. \& Berkes, F. Can partnerships and community-based conservation reverse the decline of coral reef social-ecological systems? Int. J. Commons 8, (2014).

48. Doherty, O. et al. Report on Menjangan Island's coral reef: A Bali Barat National Park marine protected area. Atoll Res. Bull. 19, 1-18 (2013).

49. SER. Society for ecological restoration international science \& policy working group. (2004).

50. Parsons, E. C. M., MacPherson, R. \& Villagomez, A. Marine "conservation": you keep using that word but I don't think it means what you think it means. Front. Mar. Sci. 4, 299 (2017).

51. Rodríguez-Martínez, R. E. Community involvement in marine protected areas: the case of Puerto Morelos reef, México. J. Environ. Manage. 88, 1151-1160 (2008).

52. Kittinger, J. N. et al. Restoring ecosystems, restoring community: socioeconomic and cultural dimensions of a community-based coral reef restoration project. Reg. Environ. Chang. 16, 301-313 (2016).

53. Camargo, C. et al. Community involvement in management for maintaining coral reef resilience and biodiversity in southern Caribbean marine protected areas. Biodivers. Conserv. 18, 935-956 (2009). 
54. Ginaya, G. The Balinese calendar system: From its epistemological perspective to axiological practices. Int. J. Linguist. Lit. Cult. 4, 24-37 (2018).

55. Suadi, N. M. Sharing the commons: resolving the tragedy of the commons through collaborative Management of Coastal Commons at Kedonganan Village. Bali. J Kyosei Stud 3, 263-285 (2009).

56. Yunitawati, D. \& Clifton, J. Governance in the early stages of marine protected area development: A case study of Nusa Penida District Marine Conservation Area, Indonesia. Mar. Policy 103653 (2019).

57. Wardana, A. Contemporary Bali: Contested Space and Governance. (Palgrave Macmillan, 2019). doi:https://doi.org/10.1007/978-981-13-2478-9.

58. De Brauwer, M. et al. The economic contribution of the muck dive industry to tourism in Southeast Asia. Mar. Policy 83, 92-99 (2017).

59. Cinner, J. E. et al. Comanagement of coral reef social-ecological systems. Proc. Natl. Acad. Sci. 109, 5219-5222 (2012).

60. Gidman, W. K., Hassell, K., Day, J. \& Payne, K. The impact of increasing workloads and role expansion on female community pharmacists in the United Kingdom. Res. Soc. Adm. Pharm. 3, 285-302 (2007).

61. Legare, C. H. et al. Perinatal risk and the cultural ecology of health in Bihar, India. Philos. Trans. R. Soc. B 375, 20190433 (2020).

62. Wager, E. \& Williams, P. "Hardly worth the effort"? Medical journals' policies and their editors' and publishers' views on trial registration and publication bias: quantitative and qualitative study. Bmj 347, (2013).

63. Patton, M. Q. Qualitative research \& evaluation methods: Integrating theory and practice. (Sage publications, 2014).

64. Grimm, K. E. \& Needham, M. D. Moving beyond the "I" in motivation: Attributes and perceptions of conservation volunteer tourists. J. Travel Res. 51, 488-501 (2012).

65. Marshall, B., Cardon, P., Poddar, A. \& Fontenot, R. Does sample size matter in qualitative research?: A review of qualitative interviews in IS research. J. Comput. Inf. Syst. 54, 11-22 (2013).

66. Morse, J. M. Determining sample size. (2000).

67. Mason, M. Sample size and saturation in PhD studies using qualitative interviews. in Forum qualitative Sozialforschung/Forum: qualitative social research vol. 11 (2010).

68. Charmaz, K. Constructing grounded theory: A practical guide through qualitative analysis. (sage, 2006).

69. Dworkin, S. L. Sample size policy for qualitative studies using in-depth interviews. (2012).

70. McKinley, E. \& Ballinger, R. C. Welsh legislation in a new era: A stakeholder perspective for coastal management. Mar. Policy 97, 253-261 (2018).

71. Saldaña, J. The coding manual for qualitative researchers. (sage, 2021).

72. O. Nyumba, T., Wilson, K., Derrick, C. J. \& Mukherjee, N. The use of focus group discussion methodology: Insights from two decades of application in conservation. Methods Ecol. Evol. 9, 20- 
32 (2018).

73. Braun, V. \& Clarke, V. Using thematic analysis in psychology. Qual. Res. Psychol. 3, 77-101 (2006).

74. Garcia, B., Fang, M. M. \& Lin, J. Marine plastic pollution in Asia: All hands on deck! Chinese J. Environ. Law 3, 11-46 (2019).

75. Sur, C. et al. Marine debris on small islands: Insights from an educational outreach program in the Spermonde Archipelago, Indonesia. Front. Mar. Sci. 5, 35 (2018).

76. Shuker, I. G. \& Cadman, C. A. Indonesia-Marine debris hotspot rapid assessment: synthesis report. (2018).

77. Lestari, P. \& Trihadiningrum, Y. The impact of improper solid waste management to plastic pollution in Indonesian coast and marine environment. Mar. Pollut. Bull. 149, 110505 (2019).

78. Suteja, Y. et al. Spatial and temporal distribution of microplastic in surface water of tropical estuary: Case study in Benoa Bay, Bali, Indonesia. Mar. Pollut. Bull. 163, 111979 (2021).

79. Germanov, E. S. et al. Microplastics on the menu: plastics pollute indonesian manta ray and whale shark feeding grounds. Front. Mar. Sci. 6, 679 (2019).

80. Barnes, D. K. A., Galgani, F., Thompson, R. C. \& Barlaz, M. Accumulation and fragmentation of plastic debris in global environments. Philos. Trans. R. Soc. B Biol. Sci. 364, 1985-1998 (2009).

81. Wardana, A. A. G. O. P., Utama, M. S., Yasa, I. N. M. \& Budiasa, I. G. S. Effect of Cummunity Participation, Tourism Infrastructure, Tourist Visit to The Tourism Industry Performance and The Quality Living Community in Bali Indonesia. Int. J. Sustain. Educ. Glob. Creat. Econ. 1, 79-86 (2018).

82. Khayrulloevna, A. M. The substantial economic benefits of tourism. Academy (2020).

83. Tomomi, I. Ecotourism in Bali: Backgrounds, present conditions and challenges. Unpubl. Dr. thesis). Ritsumeikan Univ. Kyoto, Japan (2010).

84. Byczek, C. Blessings for All? Community-Based Ecotourism in Bali Between Global, National, and Local Interests-A Case Study. Austrian J. South-East Asian Stud. 4, 81-106 (2011).

85. Chong, K. L. The side effects of mass tourism: the voices of Bali islanders. Asia Pacific J. Tour. Res. 25, 157-169 (2020).

86. Wall, G. Is ecotourism sustainable? Environ. Manage. 21, 483-491 (1997).

87. Hilbertz, W. H. \& Goreau, T. J. Method of enhancing the growth of aquatic organisms, and structures created thereby. (1996).

88. Khamdevi, M. \& Bott, H. Rethinking tourism: Bali's failure. in IOP Conference Series: Earth and Environmental Science vol. 12612171 (IOP Publishing, 2018).

89. Santos, M. N. \& Monteiro, C. C. The Olhao artificial reef system (south Portugal): fish assemblages and fishing yield. Fish. Res. 30, 33-41 (1997).

90. Ramos, J., Lino, P. G., Himes-Cornell, A. \& Santos, M. N. Local fishermen's perceptions of the usefulness of artificial reef ecosystem services in Portugal. PeerJ 6, e6206 (2019).

91. Lenihan, H. S. et al. Evidence that spillover from Marine Protected Areas benefits the spiny lobster (Panulirus interruptus) fishery in southern California. Sci. Rep. 11, 1-9 (2021). 
92. Di Lorenzo, M., Guidetti, P., Di Franco, A., Calò, A. \& Claudet, J. Assessing spillover from marine protected areas and its drivers: A meta-analytical approach. Fish Fish. 21, 906-915 (2020).

93. Komyakova, V., Chamberlain, D., Jones, G. P. \& Swearer, S. E. Assessing the performance of artificial reefs as substitute habitat for temperate reef fishes: Implications for reef design and placement. Sci. Total Environ. 668, 139-152 (2019).

94. Edgar, G. J. et al. Global conservation outcomes depend on marine protected areas with five key features. Nature 506, 216-220 (2014).

95. Goñi, R., Badalamenti, F. \& Tupper, M. H. Fisheries-Effects of marine protected areas on local fisheries: evidence from empirical studies. Mar. Prot. areas A Multidiscip. approach 72, 73 (2011).

96. Stem, C. J., Lassoie, J. P., Lee, D. R. \& Deshler, D. J. How'eco'is ecotourism? A comparative case study of ecotourism in Costa Rica. J. Sustain. Tour. 11, 322-347 (2003).

97. Cherkaoui, S., Boukherouk, M., Lakhal, T., Aghzar, A. \& El Youssfi, L. Conservation Amid COVID-19 Pandemic: Ecotourism Collapse Threatens Communities and Wildlife in Morocco. in E3S Web of Conferences vol. 1831003 (EDP Sciences, 2020).

98. Harsono, S. The impact of Covid-19 on marine ecotourism in Tegal City. in E3s Web of conferences vol. 2027020 (EDP Sciences, 2020).

99. Parker, L. \& Prabawa-Sear, K. Environmental Education in Indonesia: Creating Responsible Citizens in the Global South? (Routledge, 2019).

100. Littledyke, M. Science education for environmental awareness: approaches to integrating cognitive and affective domains. Environ. Educ. Res. 14, 1-17 (2008).

101. Strieder Philippssen, J., Soares Angeoletto, F. H. \& Santana, R. G. Education level and income are important for good environmental awareness: a case study from south Brazil. Ecol. austral 27, 3944 (2017).

102. Varela-Candamio, L., Novo-Corti, I. \& García-Álvarez, M. T. The importance of environmental education in the determinants of green behavior: A meta-analysis approach. J. Clean. Prod. 170, 1565-1578 (2018).

103. Jose, S., Patrick, P. G. \& Moseley, C. Experiential learning theory: the importance of outdoor classrooms in environmental education. Int. J. Sci. Educ. Part B 7, 269-284 (2017).

104. Williams, K. C. \& Page, R. A. Marketing to the generations. J. Behav. Stud. Bus. 3, 37-53 (2011).

105. Western, D. Conservation science in Africa and the role of international collaboration. Conserv. Biol. 17, 11-19 (2003).

106. Delello, J. A., McWhorter, R. R. \& Camp, K. M. Using social media as a tool for learning: A multidisciplinary study. Int. J. e-learning 14, 163-180 (2015).

107. Hipólito, J. The sensorial effect: Dynamics of emotion in pro-environmental behavior. Appl. Environ. Educ. Commun. 10, 189-200 (2011).

108. Soliman, M., Peetz, J. \& Davydenko, M. The impact of immersive technology on nature relatedness and pro-environmental behavior. J. Media Psychol. (2017). 
109. McCambridge, J., De Bruin, M. \& Witton, J. The effects of demand characteristics on research participant behaviours in non-laboratory settings: a systematic review. PLoS One 7, e39116 (2012).

110. Waayers, D., Lee, D. \& Newsome, D. Exploring the nature of stakeholder collaboration: A case study of marine turtle tourism in the Ningaloo region, Western Australia. Curr. Issues Tour. 15, 673-692 (2012).

111. Syam, A. R., Edrus, I. N. \& Hartati, S. T. Coral fish population changes in the surrounding artificial reefs of the Lebah coastal waters, Karangasem, Bali. Indones. Fish. Res. J. 13, 101-116 (2017).

112. Puspasari, R., Wiadnyana, N. N., Hartati, S. T., Rachmawati, R. \& Yahya, Y. The Effectiveness of Artificial Reefs in Improving Ecosystem Health to Increase Coral Reef Resilience. J. Segara 16, 115126 (2020).

\section{Figures}
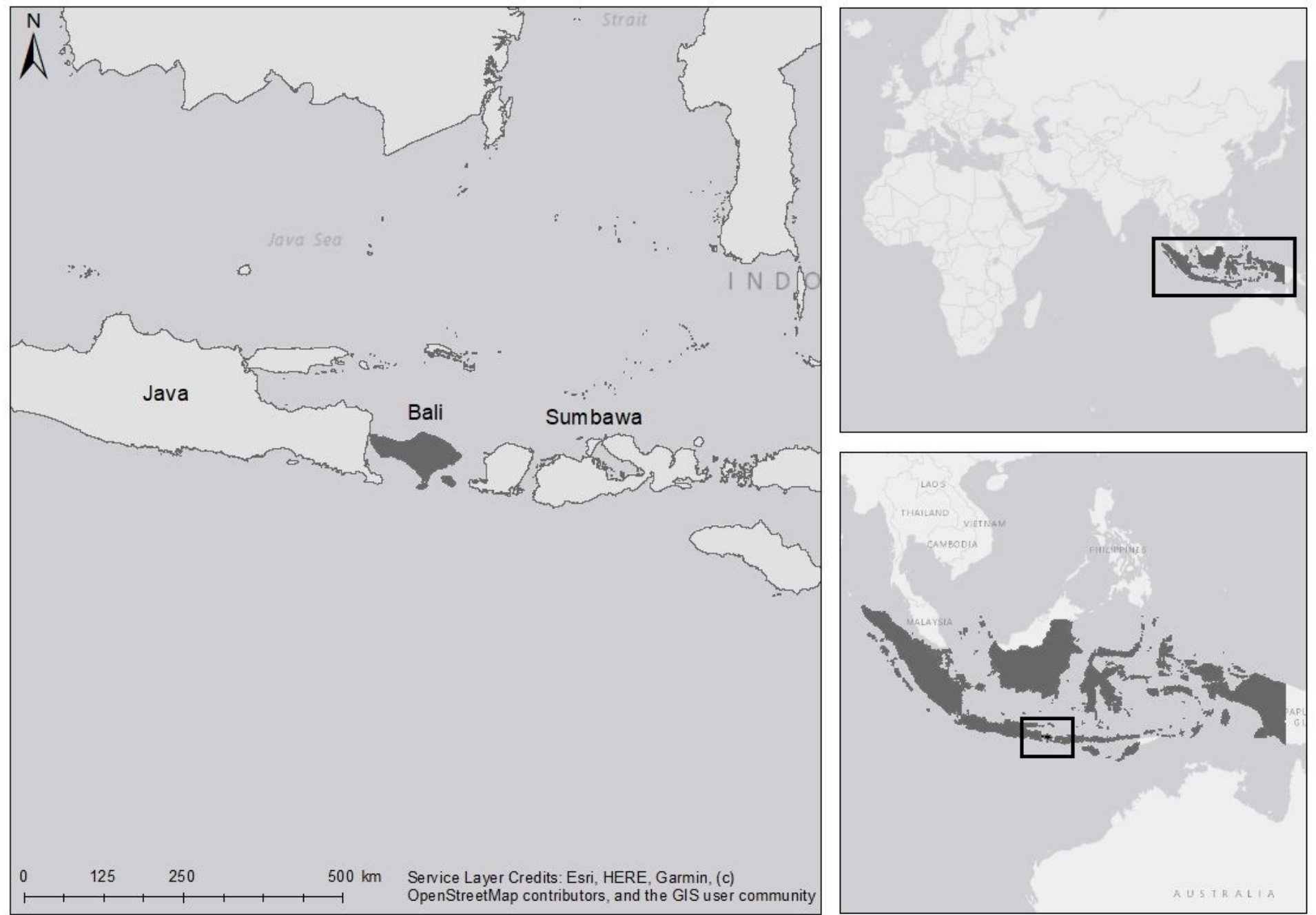

\section{Figure 1}

Location of Bali within Indonesia. 
(Created using ArcGIS OpenStreetMap powered by Esri). 